ISSN: $2355-2158$

DOI:

Cite this as:

Harahap, rachmita Maun et al. Implementation of Universal Design Concept on Lecture Space for Students with Hearing Disabilities. Indonesian Journal of Disability Studies (IJDS).201x: Vol. 6(2): PP 193-201.

\title{
Implementation of Universal Design Concept on Lecture Space for Students with Hearing Disabilities
}

\author{
Rachmita Maun Harahap*1, Imam Santosa ${ }^{2}$, Deddy Wahjudi ${ }^{3}$, Widjaja Martokusumo ${ }^{4}$ \\ ${ }^{1}$ Doctoral Program in Science of Art and Design, Bandung Institute of Technology,Indonesia, \\ 2,3,4 Bandung Institute of Technology, Indonesia
}

\begin{abstract}
Campus building is where students undergo of learning process and perform various activities. In learning process, campus should provide universal design facilities for students all, including students with disabilities. The design of campus is important factor in operation and service of a higher education. Universal design concept of lecture space in CADL ITB building can make it easier of activity for students with hearing disabilities. The purpose of this research is test a universal design strategy for reducing hearing impairment, visual communication barriers and assistive technology strengthen, but universal design concept to hearing disabilities that is much different and usually involves visual signs. This research uses 3 stages of method that is descriptive qualitative and classification analysis method. Using the parameters of universal design principles, factors involved in application can be classified to determine the problem of lecture space in CADL ITB buidling as a case study. Then observation of interview result through questionnaire of 60 respondents of students / alumni / drop out of hearing disability in various universities stated that it is still difficult to be accessed in lecture space because there is no universal design facility available. While informants 10 persons academic and not academic people understand and universal design knowledge for disabled except hearing disability. Research results of this study indicate that universal design concept in lecture space in CADL ITB building not optimal, then existing problems will be given a design solution to maximize of universal design concept.
\end{abstract}

Keywords: universal design, lecture space, hearing disabilities, CADL ITB building

\section{INTRODUCTION}

\section{A. Background}

Interior Design is not just the science of indoor design that meets the basic needs, functions and aesthetics. These three things are indeed a major 'task' in interior design. Each space is designed for the development of functions and supporting elements. Offices, airports, stations, and hotels or apartments, for example, serve as accommodation facilities. An Universal Design in a public space should be accessible and user by a variety of different needs. Hearing disabilities barrier obstacles to Universal Design that applied to the needs are much clearer and usually involve visual cues.

\footnotetext{
* Corresponding author: Rachmita Maun Harahap rachmita.mh@mercubuana.ac.id

Published online at http://IJDS.ub.ac.id/

Copyright (C) 2019PSLD UB Publishing. All Rights

Reserved
}

As a human, hearing disabilities have the same rights to obtain education and accessibility of proper buildings and accommodation has been regulated in the 1945 Constitution as well as the concern of the world community through the UN and UNCRPD Act No. 19 of 2011 on the Convention on the Rights of Persons with Disability. One of the rights guaranteed is the opportunity to run all of its activities easily, safely, conveniently as realized through the availability of accessibility facilities or universal design. In Indonesia the availability of universal design is regulated in more detail in Law No. 8 of 2016 concerning Persons with Disabilities in article 18 Accessibility section $b$ reads "to obtain adequate accommodation as a form of accessibility for individuals" while Article 19 of Public Service for b reads "mentoring, translation and the provision of easily accessible 
facilities in public services at no additional cost "and Regulation of the Minister of Research, Technology and Higher Education No. 46 of 2017 on Special Education and Special Education Service in Universities. Both of these national-level regulations require every public building including the university to meet the 7 principles of Universal Design standards. The lecture space at campus is one of the main functions used by all students including disability, so the lecture space at university meets the nationally regulated universal design regulation standards.

\section{B. Definition of Hearing Disabilities}

Hearing disabilities is a person experiencing a deficiency or loss of good ability or that can"t be done with hearing aids so that he can't use his hearing devices in everyday life (Bunawan, 1990 in RM Harahap, 1995). There are several categories of hearing disabilities as follows are : Deaf-verbal, Deafsign language, Deafverbal/sign language, and Hard of Hearing $(\mathrm{HOH})$ are categories of hearing impairment that can only hear above $91 \mathrm{~dB}$ (Moores, 1995). In this category, students with hearing disability are unlikely to have normal conversations, and many are deaf to the public.

There are three different types of hearing loss: (N. Christian. DHL: Causes,Symptoms and Treatments, 2015) foolows as :

1) Conductive hearing loss. This means that the vibrations are not passing through from the outer ear to the inner ear, specifically the cochlea. It can be due to an excessive build-up of earwax, glue ear, an ear infection with inflammation and fluid buildup, a perforated eardrum, or a malfunction of ossicle (bones in the middle ear). Also, the eardrum may be defective. Ear infections can leave scar tissue, which damages the functioning of the ear drum, and ossicle may be impaired due to infection, trauma, or their fusing together (ankylosis). 2) Sensorineural hearing loss. Hearing loss is caused by dysfunction of the inner ear, the cochlea, auditory nerve, or brain damage. Usually, this kind of hearing loss is due to damage of the hair cells in the cochlea. As humans get older, the hair cells lose some of their function, and our hearing gets worse. In Western Europe and North America, it is estimated that over half of all people over 70 have hearing impairment caused by degenerated hair cells in the cochlea. Long-term exposure to loud noises, especially high-frequency sounds, is another common reason for hair cell damage. Damaged hair cells cannot be replaced. Currently, research is looking into using stem cells to grow new ones. Sensorineural total deafness may be due to birth defects, inner ear infections, or head trauma. If the eardrum and middle ear are functioning properly, patients may benefit from a cochlear implant - a thin electrode is inserted into the cochlea, it stimulates electricity through a tiny microprocessor that is placed behind the ear, under the skin. 3) Mixed hearing loss. This is a combination of conductive and sensorineural hearing loss. Long-term ear infections can damage both of eardrum and ossicle. Sometimes, surgical intervention may restore hearing, but it does not always work.

Based on these three classifications, it can be concluded that hearing loss is a listening ability, including the ability to capture, distinguish, or listen to sound, which is below normal listening ability.

\section{Definition of Universal Design}

Definition of universal design is while concept of universal design emerged primarily with people with disability in mind, universal design helps everyone with support and assistance needs including the elderly, pregnant women, children and people with a temporary illness or injury. Thus benefits of implementing universal design are wide. 7 principles of universal design application will support practitioners to better meet the needs of as many users as possible. When working in developing countries, it is important to also take into account cultural, economic, engineering, environmental, gender and social contexts. According to Ron Mace, The Center of Universal Design, 1997 universal design is a philosophy in designing an with Hearing Disabilities. Indonesian Journal of Disability Studies (IJDS).201x: Vol. 6(2): PP 193-201. 
appropriate and enabling environment for everyone without the need for great adaptation. In addition to providing easy access for people with disabilities, universal design is also aimed at parents, pregnant women, children, and foreigners. Universal design contains 7 main principles, namely (Mace, 1997): Principle 1: Equitable use; Design that is useful and marketable to persons with diverse abilities. Principle 2: Flexibility in use; Design that accommodates a wide range of individual preferences and abilities. Principle 3: Simple and intuitive use; Design that is easy to understand, regardless of the user's experience, knowledge, language skills, or concentration level. Principle 4: Perceptible information; Design that communicates necessary information effectively to the user, regardless of ambient conditions or the user's sensory abilities. Principle 5: Tolerance for error ; Design that minimizes hazards and the adverse consequences of accidental or unintended actions. Principle 6: Low physical effort ; Design that can be used efficiently and comfortably and with a minimum of fatigue.

Principle 7: Size and space for approach and use ; Design that provides appropriate size and space-for approach, reach, manipulation, and use, regardless of the user's body size, posture or mobility .

These principles apply generally to all areas of design, architecture, interior, products, etc., primarily in the form of facilities and products of public facilities. In particular, these principles can also be applied to private facilities with special needs. These principles offer designers guidance to better integrate features that meet the needs of as many users as possible.

\section{Important factors in the application of Universal Design}

In universal design application requires factors that are essential to support success in universal design projects. Factors to note are Deaf Space design guidelines, which are applied in five aspects of the building include the arrangement of (Bauman, 2008): (a) Space and proximity; spatial orientation and the awareness of activities within our surroundings are essential to maintaining a sense of well-being. Deaf people "read" the activities in their surroundings that may not be immediately apparent to many hearing people through an acute sensitivity of visual and tactile cues such as the movement of shadows, vibrations, or even the reading of subtle shifts in the expression/position of others around them, (b) Sensory reach or visually ; in order to maintain clear visual communication individuals stand at a distance where they can see facial expression and full dimension of the signer's "signing space". There space between two signers tends to be greater than that of a spoken conversation. As conversation groups grow in numbers the space between individuals increases to allow visual connection for all parties. This basic dimension of the space between people impacts the basic layout of furnishings and building spaces, (c) Mobility and Proximity; while walking together in conversation signers will tend to maintain a wide distance for clear visual communication. The signers will also shift their gaze between the conversation and their surroundings scanning for hazards and maintaining proper direction, (d) Lights and colour ; Poor lighting conditions such as glare, shadow patterns, backlighting interrupt visual communication and are major contributors to the causes of eye fatigue that can lead to a loss of concentration and even physical exhaustion. Proper Electric lighting and architectural elements used to control daylight can be configured to provide a soft, diffused light "attuned to deaf eyes". Color can be used to contrast skin tone to highlight sign language and facilitate visual wayfinding and (e) acoustic ; deaf individuals experience many different kinds and degrees of hearing levels. Many use assistive devices such as hearing aids or cochlear implants to enhance sound. No matter the level of hearing, many deaf people do sense sound in a way that can be a major distraction, especially for individuals with assistive hearing devices.

Cite this as:

Harahap, Rachmita Maun et al. Implementation of Universal Design Concept on Lecture Space for Students with Hearing Disabilities. Indonesian Journal of Disability Studies (IJDS).201x: Vol. 6(2): PP 193-201. 
Reverberation caused by sound waves reflected by hard building surfaces can be especially distracting, even painful, for individuals using assistive devices. Spaces should be designed to reduce reverberation and other sources of background noise

The visual behavior access set forth in the deaf space guidelines has 5 main aspects. However, given the different scope of 7 universal design principles, the five aspects can't be directly implemented in the design. The researcher tries to bridge 5 aspects related to visual behavior access for users of hearing disability in deaf space guidance with 7 universal design principles through integration concepts. This is intended to facilitate the designer in applying access to visual behavior based on deaf space while applying the rules of universal design.
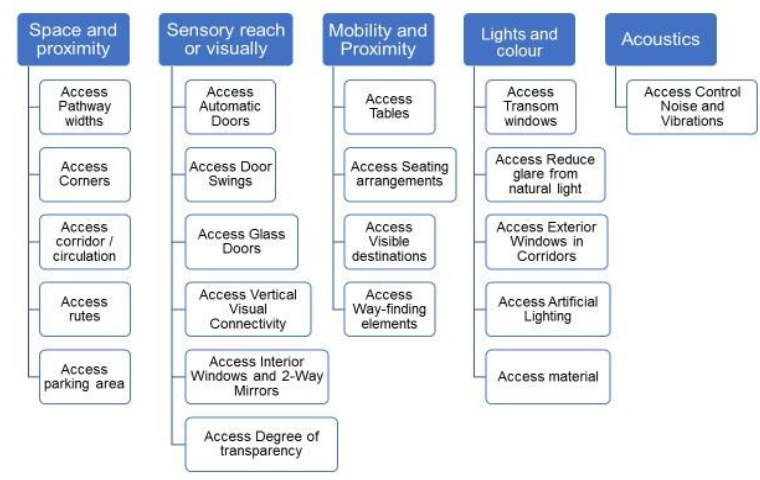

Figure 2. An important factor in the application of universal design (specifically deaf space design guidelines) Source : RM. Harahap, 2017

Judging from division of factors that exist, then in application of universal design of lecture space in the building CADL ITB requires factors only tailored to the topic of discussion, namely Deaf Space design guidelines, which are applied in five aspects of the building include the arrangement of (a) space and proximity : access pathway widths, access corners, access corridor / circulation, access rutes, and access parking area, (b) sensory reach or visually : access automatic doors, access door swings, access glass doors, access vertical visual connectivity, access interior windows and 2-way mirrors, and access degree of transparency, (c) mobility and
Proximity : access tables, access seating arrangements, access visible destinations, access way-finding elements, (d) Lights and colour : access transom windows, access reduce glare from natural light, access exterior windows in corridors, access artificial lighting and access material, and (e) acoustics : access control noise and vibrations.

\section{METHOD}

The research method used is qualitative descriptive method and survey with interview technique to get requirement of data from research subject, that is student/alumni with hearing disabilities. This research is evaluative, that is analyzing aspect of visual behavior on lecture spacethrough standard of universal design principles that is sidewalk, circulation, corner wall, door and window, arrangement of table and chair, lighting and color and etc. The research results showed that concept of new lecture room design from design that has not met of universal design standards on room element. The method used is descriptive qualitative and survey method with interview technique to get the data requirement from research subject, that is students or alumni of hearing disabilities 60 persons respondents and informants of 10 persons academic and non-academic of currently working close to students with disabilities participated in this study.

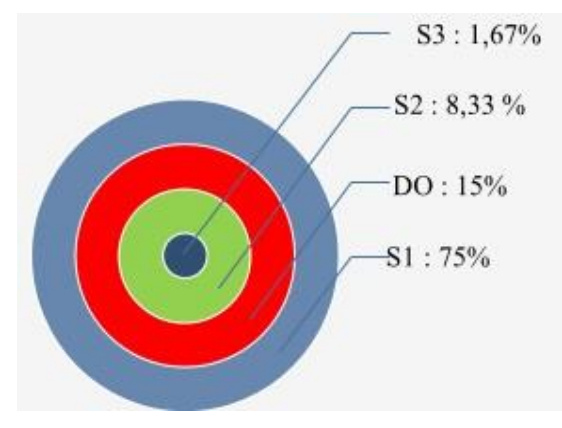

Figure 2 shows most of the respondents of students or alumni with hearing disability in this study were in the age rangen 17-25 (55\%) and the male sex more than women. In terms of education level of most respondents S1 (75\%), 
where there students drop out of college (15\%) because not access.

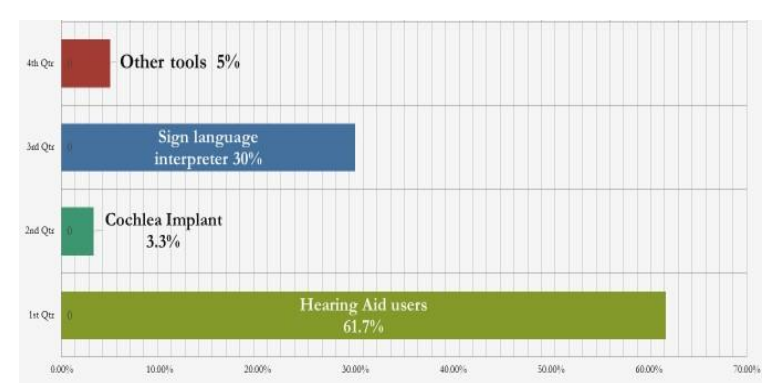

Figure 3 shows the respondents needs of most using hearing aid is $61,7 \%$, however the lecture space services and assistive technology aren't accessible.

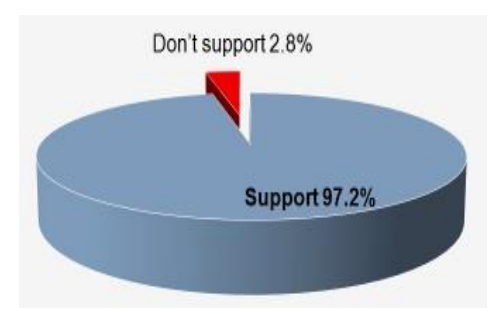

Figure 4 shows most of the respondents needs access of lecture space and assistive technology to be given opportunities and equality with other students.

The case study in this study was taken samples of CADL-ITB building located ITB complex in Bandung city, which aims to review the campus alignment to students who have different needs from the design side.

Data analysis methods used include:

1. Descriptive data analysis method; descriptive method in the form of embodiment of words. Qualitative data is the source of a broad description and more emphasis on meaning and bound value. Qualitative research is used to identify hidden meanings, to understand social interactions, to ensure data validity, and to develop existing substantive theories.

2. Method of analysis of data classification: the literature data about universal design and lecture space that is made into parameters and classified into 3 parts, namely: optimal (4), optimal enough (3), Sub optimal (2) and No access (1). The classification aims to find out the factors of universal design including which parameter classification. Universal design factors that include optimal classification (3) and Sub optimal (2) are factors that have problems in the application of universal design.

\section{DISCUSSION RESULT}

ITB campus located in the Bandung city with an area of $81.425,53 \mathrm{M} 2$ or 8.14 hectares (Data Directorate SP-ITB, 2017). The location of the CADL building is part of the Bandung Institute of Technology complex located in Ganesha. This CADL building of amount to 7 floors consists of several functions of the spaces, that is lecture class room, studio room, practice room, lecturers room, meeting room, courtroom, laboratory, staff room, trial, workshop, display room, toilet and mushola. This is important in order to accommodate everyone with different abilities.

The building mass in Figure 6 is 7 floors, based on space program data as follows: $1^{\text {st }}$ floor FSRD entrance hall and Language Center, $2^{\text {nd }}$ and $3^{\text {rd }}$ floor lecturer rooms and lecturers' meeting room and staff administration TU majors room, $4^{\text {th }}, 5^{\text {th }}, 6^{\text {th }}$ and $7^{\text {th }}$ floor class theory room, practice or workshop room, studio room and courtroom.

The universal design application on lecture room in CADL is analyzed by classifying factors aspect visual perception for hearing disabilities. Classification is based on universal design parameters that can be used to determine the level of conformity of standard factors 7 universal design principles. Objects that will be analyzed to produce factors that are not in accordance with universal design standards will be proposed solution design for problems that exist in lecture space. From the results of existing data analysis and design solutions will be found conclusion of the application of the concept of universal design elements in lecture room. 


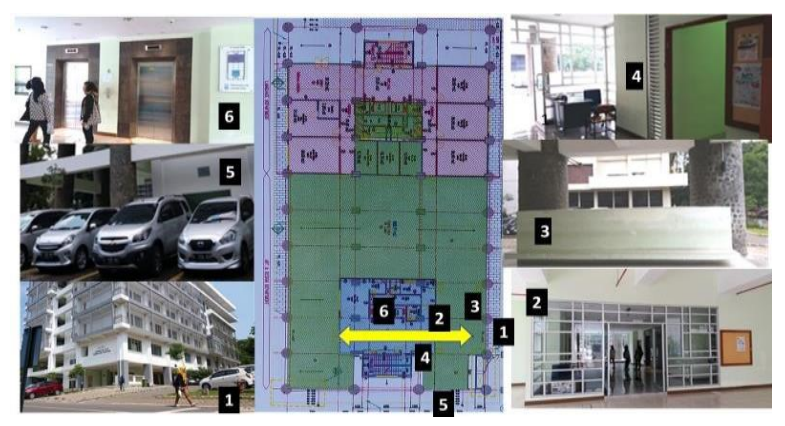

Figure 6 Access horizontal. Denah $1^{\text {st }}$ floor CADL-ITB Source Doc. Rachmita MH, 2017

The visual signs/marks on the exterior and interior of this lecture room at CADL ITB building including no access classification (1) because it doesn't meet of universal design standard the $2^{\text {nd }}$ and $4^{\text {th }}$. No signs are used, so it is difficult to understand for users. Should lay out a strategic mark, the use of contrasting colors and large sizes can be seen for all users.

Parking area serves parking space and circulation, the need for visual behavior access is to know the existence of vehicles passing in front or behind the surrounding. Visual behavior access function is a view, self-protection and natural supervision. The parking area works in the parking lot. The function of visual behavior access is viewing, self-protection and natural surveillance.

Breezeway serves the interconnection between buildings and circulation, the need is to know conditions outside the hall, in buildings and wayfinding (when first come). The function of visual behavior access is viewing, selfprotection, natural surveillance and wayfinding.

See Figure $6 . .1$ access corridor from parking area to entrance including of sub optimal classification (2) because haven't parking for disabilities (Figure 6.5) . Figure 6.2 access entrance to lobby at CADL ITB building including of sub optimal classification (2) because it doesn't meet of universal design standards the $1^{\text {st }}, 5^{\text {th }}$ and $7^{\text {th }}$. Figure 6.6 access entrance to elevators area including of medium classification (3) it meet enough of universal design standard. Figure 6.3 waiting area and security desk (Figure 6.4) including of sub optimal classification (2) because it doesn't meet of universal design standards the $4^{\text {th }}$ nothing visual signs/marks no sign of space for whom in the hall area.

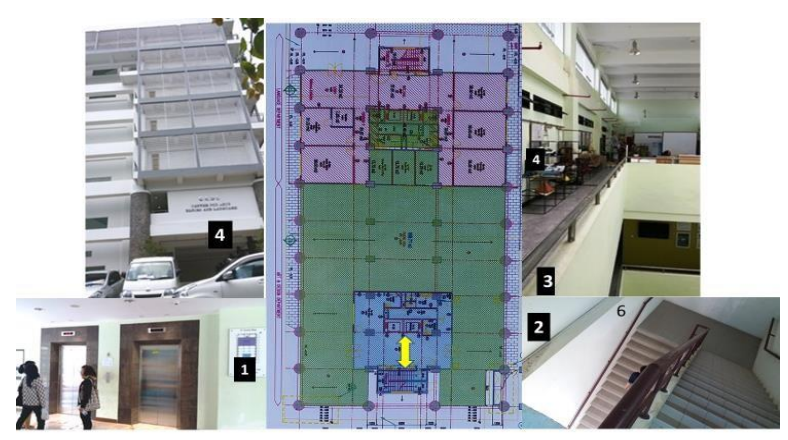

Figure 7. Access vertical - access betweem rooms $1^{\text {st }}$ floor to $7^{\text {th }}$ floor. Denah $1^{\text {st }}$ floor CADL-ITB Source Doc. Rachmita MH, 2017

Figure 7.1 access corridor to elevators area and stairs (Figure 7.2) including of medium classification (3) because elevators and corridors fit universal design standards the $1^{\text {st }}, 5^{\text {th }}$ and $7^{\text {th }}$. Access floor to lecture room (Figure 7.4) of vertical visual connectivity (Figure 7.3) including of classification medium (3) it meet enough of universal design standards the $1^{\text {s }}, 3^{\text {th }}$, $5^{\text {th }}$ and $6^{\text {th. }}$ Visible information board next to the elevators is sufficient access for hearing student disabilities students including universal

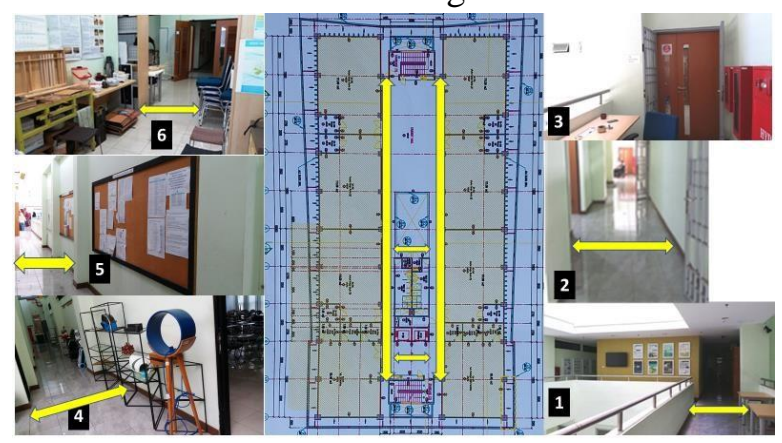

Figure 8. Access corridor circulation to lecture class room. Denah $7^{\text {th }}$ floor CADL-ITB. Source Doc. Rachmita MH, 2017

Access circulation to lecture room including of sub optimal classification (2) because pathway width narrowed (all figure 8) t doesn't meet of universal design standards the $1^{\text {st }}, 5^{\text {th }}$ and $6^{\text {th }}$. Pathways should be 8 ' wide minimum, also no visual signs/marks it doesn't meet of universal design standard the $4^{\text {th }}$. There are accommodated of student work items (Figure 8.4) and even bulletin boards will disturb people

Cite this as:

Harahap, Rachmita Maun et al. Implementation of Universal Design Concept on Lecture Space for Students with Hearing Disabilities. Indonesian Journal of Disability Studies (IJDS).201x: Vol. 6(2): PP 193-201. 
through the corridor (Figure 8.5) including of sub optimal classification (2) because it doesn't meet of universal design standard the $1^{\text {st }}, 2^{\text {th, },} 5^{\text {th }}$ and $6^{\text {th }}$. Visible staff room on the lid without any information signs of what is space will be harder hearing disabilities users (Figure 8.3) including of classification sub optimal (2) because it doesn't meet of universal design standard the $1^{\text {st }}$, $4^{\text {th }}, 5^{\text {th }}$ and $6^{\text {th }}$.

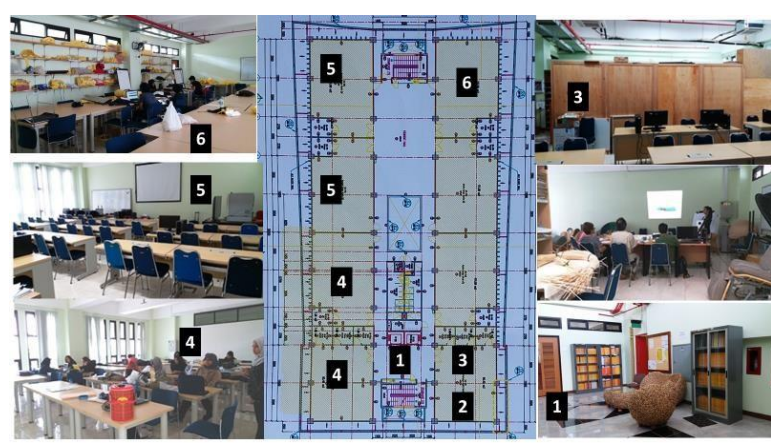

Figure 9. Seating arrangements and tables on lecture class room. Denah $7^{\text {th }}$ floor CADL-ITB. Source Doc. Rachmita MH, 2017

Lecture classroom (theory, studio, practice) function learning, practice, trial and seminars. The need is to know the condition of the outdoors (if own) and the people inside (if being in college and there are others), while the visual behavior access function is viewing, selfprotection and natural surveillance.

See this classroom theory (Figure 9) includes the sub optimal classification (2), as it does not meet universal design standard the $1^{\text {st }}, 2^{\text {nd }}, 4^{\text {th }}, 5^{\text {th }}$ and $7^{\text {th }}$. In the layout seating arrangements and tables in the classroom theory is not provided a U-shaped arrangement then the students with hearing disability is difficult to access because they are usually visual communication through mimic mouth Lecturer was talking. That take the form of circles or half-circles are most effective in granting everyone equal visual access. Visible theory classroom and a separate courtroom (Figure 9.2) cabinets closed (Figure 9.3) including of classification sub optimal (2) because can interfere with noise from the adjacent room without walls. Layout of seating arrangement and tables can be seen the desired area through the existing visual behavior access elements, don't back to the elements or block people see elements.

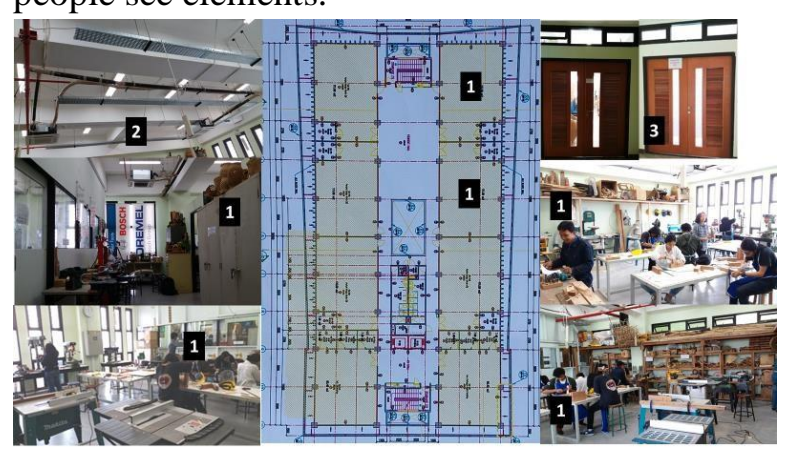

Figure 10. Light and colour and acoustic . Denah $7^{\text {th }}$ floor CADL-ITB Source Doc. Rachmita MH, 2017

See figure 16 lighting in lectura space including moderate classification (3) because it meets universal design standards that are complete on 1, 4, 5 and 6. Lighting during the day is sufficient to be met through window openings. Thus, natural lighting through window openings is quite adequate. At night use artificial lighting using incandescent lamps, which provide quality warm light with the intensity of light intensity that remains distributed evenly, not blinding, and does not cause shadows.

\section{CONCLUSION}

The results of data analysis derived from field data and literature data or universal design standards, then factor of deaf space design guidelines can be classified according to the universal design parameters. Universal design parameters are obtained through the data literature or universal design standards. This is the result of conclusion in accordance with the formulation of existing problems.

Suggestions and recommendation, the researcher proposes a solution design in accordance with universal design principles for hearing disabilities. For the development of the next campus, should the university parties have planned the universal design application on all the factors of universal design, in order to provide facilities for students with hearing disability and government parties of the Ministry 
of PUPR can accommodate the universal design for hearing disabilities into the Ministry of PUPR regulation book number 14 year 2017 and also Ministry of Research and Technology of Higher Education number 46 year 2017. So that community of hearing disabilities in Indonesia can enjoy life and equality of rights to environmental and building accessibility without discrimination.

\section{Bibliography}

\section{Book}

Arikunto (2010) : Prosedur penelitian sebuah pendekatan praktek. Yogyakarta, Rineka Cipta, hal. 118

Boothroyd, A. (1982). Hearing impairments in young children. New York:

Prentice Hall, Inc., Inglewoods Cliffs.

Bunawan, L. (1989). Psikologi Anak Tunarungu. Jakarta: Zinnia.

Burgstahler, Sheryl. (2012): Universal design of instruction (UDI): definition, principles, guidelines, and examples. Seattle : University of WashingtonEgual Acces ; Desigining your project to be accessibleto all participants, University of Washington, College of Engineering UW Technology Services College of Education.

Creswell, John W. (2013): Research Design Qualitative, Quantitative and Mixed Methods Approches, SAGE Publications, California.

Direktorat Sarana dan Prasarana ITB. (2017) Bandung

Goldsmith, Selwyn (2000): Universal design, a manual of practical guidance for architect, Architectural Press, Oxford.

Harahap, RM. (1995). Harahap, RM. (1995).

Pusat Rehabilitasi dan Pendidikan

Tunarungu di Jakarta Barata. Skripsi

Teknik Arsitektur Univ. Mercu Buana.

Jakarta

Kirk,Samuel A.., 2015. Educating

Exceptional Children. Arizona

Cengage Learning.

Moores, Donald F. 1995. Educating The Deaf: Psychology, Principles, and Practices.
Boston: Houghton Mifflin Company. (Book)

Peraturan Presiden RI UU No 8/2016.

(2016) Penyandang disabilitas. Jakarta

Peraturan Menteri PUPR No 14/M/PRT/2017.

(2017) : Kemudahan persyaratan

bangunan, buku Pedoman Kementerian PU

RI, Jakarta.

Peraturan Menteri Riset dan Teknologi Dikti

No 46/2017. (2017): Pendidikan khusus

dan pendidikan layanan khusus di

perguruan tinggi, Jakarta.

\section{Proceeding;}

Harahap, RM, Santosa, I; Wahjudi, D \& Martokusumo, W. (2017): The innovation of assistive technology access for students of hearing disability with a principles of Universal design approach. Proceeding National, Unesa, 28 October 2017, Surabaya .

\section{Data Situs Internet (web site)}

Bauman, Hansel. (2005). Deaf space. Gallaudet University's Architects .

(https://www.gallaudet.edu/campus-designand-planning/deafspace)

Deaf diverse design guidelines (2010), data situs internet:

https://ced.berkeley.edu/eventsmedia/events/hansel-baumandeafspace- rediscovering-somaticways-of-dwelling. (19 Oktobert 2016)

Deaf space: deaf culture meets architecture in universal design (2011), data situs http://www.rollingrains.com/2011/04/ reprinted-with-permissiondeafspace.html. (7 Desember 2016).

Nordqvist,Christian., 2015. Deafness and Hearing

Loss: Causes,Symptoms and Treatments

[Online] (Updated 10 Nov 2015) Available at:

http://www.medicalnewstoday.com/ articles/249285.php?page $=$. [Accessed November 2016].

The principles of universal design, NC State University College of Design, data diperoleh situs internet:

Cite this as:

Harahap, Rachmita Maun et al. Implementation of Universal Design Concept on Lecture Space for Students with Hearing Disabilities. Indonesian Journal of Disability Studies (IJDS).201x: Vol. 6(2): PP 193-201. 
IJDS 2019; Vol. 6 No. 2, November 2019, pp. 193-201

ISSN: $2355-2158$

DOI:

https://www.ncsu.edu/ncsu/design/cud/pub s_p/ docs/poster.pdf. (11 Maret 2017) with Hearing Disabilities. Indonesian Journal of Disability Studies (IJDS).201x: Vol. 6(2): PP 193-201. 